\title{
Synthesis and Application of Functional (Anti- UV) Azo - dyes on Nylon Fabrics: Part I
}

\author{
B. M. Youssef, M. H. M. Ahmed", M. M. H. Arief*, H.M. \\ Mashaly, R. A. Abdelghaffar and S. A. Mahmoud \\ National Research Centre, Giza and *Faculty of Science, \\ Banha University, Banha, Egypt.
}

\begin{abstract}
J INE novel azo dyes containing UV absorber (anti-UV dyes) 1 were synthesized by diazotization of primary aromatic amines (p. $\mathrm{NO}_{2}, \mathrm{p} . \mathrm{Cl}, \mathrm{p} . \mathrm{Br}$ aniline) and then coupling with $\mathrm{J}$ - acid coupler. The resultant intermediates were also diazotized and coupled with anti-UV functional finishing groups (resorcinol, 2, 4- dihydroxy benzophenone, 1- hydroxy benzotriazol sulfonic acid UV absorbers). The structure of the synthesized dyes was fully elucidated using FTIR and ${ }^{1} \mathrm{H}-\mathrm{NMR}$. All synthesized dyes were applied on nylon fabrics. Fabrics dyed with anti-UV dyes were tested for color strength $(\mathrm{K} / \mathrm{S})$, rate of fading $(\Delta \mathrm{E})$ values and fastness properties.
\end{abstract}

Keywords: Synthesis, Characterization, Azo dyes, Dyeing, Color strength (K/S), UV absorbers and Nylon fabric.

As known, UV radiation emitted by the sun in the range between 100 and 400 $\mathrm{nm}$ is subdivided into UV-C (100-280nm), UV-B (280-315nm) and UV- A (315$400 \mathrm{~nm})^{(1-4)}$

As for UV radiation type $\mathrm{C}$ which is dangerous to living species, higher layers of the atmosphere absorb this type of radiation. Human skin has to be protected against excessive radiation of the UV-B type which is proved to be dangerous in its excessive range. It was proved that excessive radiation of this range is the origin of premature skin ageing, sunburns, allergies and even skin cancer. The UV-A $(\lambda=315-400 \mathrm{~nm})$ radiation is less dangerous but also its over dose can result in similar effects as described above ${ }^{(3)}$.

Recently, UV radiation (280-400 nm) has received growing attention from researchers because of the increased levels of UV radiation reaching the earth's surface, due to stratospheric ozone depletion ${ }^{(5)}$.

Accordingly, the awareness of the need for protection against harmful UV radiation rapidly increases attention for textiles designed for protective clothing, including the protection against ultraviolet radiation (UV), which ranges from 100 to $400 \mathrm{~nm}$. $(1,3,4,6-9)$. 
Fabric color also has a fundamental importance in UV protection; dyed fabrics protect more than undyed ones and their protection levels rise with the increase in dye concentration ${ }^{(10)}$. In general, light colors reflect solar radiation more efficiently than dark ones ${ }^{(11,12)}$, allowing incident radiation to penetrate through the fabric with reflecting actions (scattering).

High light fastness of dyed materials is important especially for garment, automobile colored upholstery, which can be exposed to direct sunlight and temperature above $50^{\circ} \mathrm{C}$.

The present study is an attempt to synthesis a novel anti-UV azo dyes by incorporating an ultraviolet absorber (UVA) into a dye chromophore to obtain functional anti-UV dyes.

UV absorbers are organic or inorganic compounds which have been utilized to protect polymeric materials from photo degradation caused by sunlight or ultra-violet rich artificial light. UV absorbers are often used to protect material properties of polymers or textiles, e.g. improvement of the light fastness of textile coloration $^{(7)}$.

\section{Experimental}

\section{Materials}

Substrate

Scoured nylon fabrics $\left(172 \mathrm{~g} / \mathrm{m}^{2}\right)$ were supplied from Misr for Spinning and Weaving Company, Mahalla El- Kobra., Egypt. Nylon fabric was further treated with a solution containing $2 \mathrm{~g} / \mathrm{L}$ nonionic detergent (Hostapal ${ }^{\circledR} \mathrm{CV}$-Clariant), at $60^{\circ} \mathrm{C}$ for $30 \mathrm{~min}$, then the fabrics were thoroughly rinsed with water and air dried at room temperature.

\section{Chemicals and instrumentation}

Para nitro aniline, para chloro aniline, para bromo aniline, J- acid[ 6-amino-1naphthol -3- sulfonic acid](Fluka),resorcinol (Qualikems), 2, 4- dihydroxy benzophenone (Meark), 1- hydroxy benzotriazol(Aldrich), all other chemicals used in this study were of laboratory reagent grade.

All melting points were determined on an electrothermal digital melting point apparatus and are uncorrected. IR spectra were recorded in $\mathrm{KBr}$ disks using a PYA UNICAM spectra 1000 FT-IR spectrophotometer. 1HNMR (400MHz) spectra were recorded on a VARIAN 400MHz spectrometer in DMSO as solvent and TMS as internal standard; chemical shifts are reported in $\delta$ units (ppm). UV spectra were recorded on a Perkin Elmer Lamb 15 UV/Vis spectrophotometer.

\section{Synthesis}

Synthesis of disazo dyes (containing UV absorber) 1-3 ${ }^{(13)}$

P.Cl Aniline was diazotized by the following method: P.Cl Aniline $(1.275 \mathrm{gm}$, $0.01 \mathrm{~mol})$ was dissolved in concentrated $\mathrm{HCl}(37 \%, 3 \mathrm{ml})$, poured over ice Egypt. J. Chem. 55, No.5 (2012) 
$(50 \mathrm{gm})$ at $0^{\circ} \mathrm{C} . \mathrm{NaNO}_{2}(0.72 \mathrm{gm})$ was added dropwise over $30 \mathrm{~min}$. The reaction mixture was stirred at $0{ }^{\circ} \mathrm{C}$ for $40 \mathrm{~min}$ and the excess nitrous acid was destroyed by adding a small amount of sulphamic acid.

The resultant solution was added to $\mathrm{J}$ - acid $(2.4 \mathrm{gm}, 0.01 \mathrm{~mol})$ dissolved in the appropriate amount of aqueous sodium carbonate at $5-6^{\circ} \mathrm{C}$, over $30-45 \mathrm{~min}$ at ${ }_{\mathrm{p}} \mathrm{H}$ 8 -9. The coupling was stirred until ${ }_{\mathrm{p}} \mathrm{H}$ was stabled $\{\mathrm{T} 1\}^{(14)}$. Then the resultant mixture $\{\mathrm{T} 1\}$ was filtrated and then diazotized in a similar manner as described above $\{\mathrm{T} 1 \mathrm{~A}\}$.

Reaction of T2A with resorcinol (dye 1): (T1A, $0.01 \mathrm{~mol})$ was treated with resorcinol (1.1 gm, $0.01 \mathrm{~mol})$ dissolved in $10 \%$ sodium hydroxide $(10 \mathrm{ml})$ and the mixture was stirred at ${ }_{\mathrm{p}} \mathrm{H} 8.5$ and $8-10{ }^{\circ} \mathrm{C}$ for $1 \mathrm{hr}$. The dye was isolated by addition of $\mathrm{NaCl}(15 \% \mathrm{w} / \mathrm{v})$ at $80{ }^{\circ} \mathrm{C}$ then filtrated and dried.

Dye 1: $\lambda=495 \mathrm{~nm}, \mathrm{mp}>300{ }^{\circ} \mathrm{C}$, yield $75 \%$.

$\mathrm{C}_{22} \mathrm{H}_{14} \mathrm{~N}_{4} \mathrm{O}_{6} \mathrm{SCLNa}(520),\left[\mathrm{M}^{+}\right]=520$.

IR (KBr) vmax $/ \mathrm{cm}^{-1}: 3419(\mathrm{OH}), 1474(\mathrm{~N}=\mathrm{N}), 1275,1187,1048\left(\mathrm{SO}_{3} \mathrm{H}\right)$.

${ }^{1} \mathrm{HNMR}$ (DMSO) ppm: $\delta 12.6,12.2,10.1 \mathrm{ppm}\left(\mathrm{s}, 3 \mathrm{H}, \mathrm{OH}\right.$ disappear in $\left.\mathrm{D}_{2} \mathrm{O}\right), 8.1$ $-5.7 \mathrm{ppm}(\mathrm{m}, 11 \mathrm{H}$, aromatic $\mathrm{H})$.

Reaction of T2A with 2, 4- dihydroxy benzophenone (dye 2): (T1A,0.01 mol) was treated with 2,4 - dihydroxy benzophenone $(2.14 \mathrm{gm}, 0.01 \mathrm{~mol})$ dissolved in $10 \%$ sodium hydroxide $(16 \mathrm{ml})$, The mixture stirred at ${ }_{\mathrm{p}} \mathrm{H} 8-9$ and $8-10{ }^{\circ} \mathrm{C}$ for $1 \mathrm{hr}$. The dye was salted out by addition of $\mathrm{NaCl}(15 \% \mathrm{w} / \mathrm{v})$ at $80{ }^{\circ} \mathrm{C}$ then filtrated and dried.

Dye 2: $\lambda=500 \mathrm{~nm}, \mathrm{mp}>300{ }^{\circ} \mathrm{C}$, yield $87 \%$.

IR (KBr) vmax $/ \mathrm{cm}^{-1}$ : 3428(OH), 1619(C=O), 1493(N=N), 1270, 1219, 1053 $\left(\mathrm{SO}_{3} \mathrm{H}\right)$.

${ }^{1} \mathrm{HNMR}$ (DMSO) ppm: $\delta 12.6,12.2,10 \mathrm{ppm}\left(\mathrm{s}, 3 \mathrm{H}, \mathrm{OH}\right.$ disappear in $\mathrm{D}_{2} \mathrm{O}$ ), 7.8 $6 \mathrm{ppm}(\mathrm{m}, 15 \mathrm{H}$, aromatic $\mathrm{H})$.

\section{Preparation of dye 3}

1. Sulphonation of hydroxy benzotriazol ${ }^{(15)}$ : In $1000 \mathrm{ml}$ round -bottom flask, $20 \mathrm{gm}$ of concentrated sulfuric acid was added, followed by addition of hydroxy benzotriazol $(27 \mathrm{gm})$ with frequent shaking. The mixture was warmed until a solid homogenous compound was formed (10min). Diphenyl ether $(30 \mathrm{ml})$ was added and the mixture was refluxed for $10 \mathrm{hr}$, then cooled to room temperature and the excess of diphenyl ether was decanted.

2. Reaction of TIA with 1-hydroxy benzotriazol sulfonic acid (dye3): (T1A,0.01 mol) was treated with 1- hydroxy benzotriazol sulfonic acid (2.15gm, $0.01 \mathrm{~mol})$ dissolved in $10 \%$ sodium hydroxide $(20 \mathrm{ml})$.The reaction mixture was stirred at ${ }_{\mathrm{PH}} \mathrm{H}-9$ and $8-10{ }^{\circ} \mathrm{C}$ until ${ }_{\mathrm{PH}}$ was stabled. The dye was salted out by addition of $\mathrm{NaCl}(15 \% \mathrm{w} / \mathrm{v})$ at $80{ }^{\circ} \mathrm{C}$ then filtrated and dried.

Dye 3: $\lambda=505 \mathrm{~nm}, \mathrm{mp}>300{ }^{\circ} \mathrm{C}$, yield $81 \%$. 
IR (KBr)vmax $/ \mathrm{cm}^{-1}: 3446(\mathrm{OH}), 1495(\mathrm{~N}=\mathrm{N}), 1269,1229,1053\left(\mathrm{SO}_{3} \mathrm{H}\right)$.

${ }^{1} \mathrm{HNMR}$ (DMSO) ppm: $\delta 12,10 \mathrm{ppm}\left(\mathrm{s}, 2 \mathrm{H}, \mathrm{OH}\right.$ disappear in $\left.\mathrm{D}_{2} \mathrm{O}\right), 7.9-6 \mathrm{ppm}(\mathrm{m}$, $10 \mathrm{H}$, aromatic $\mathrm{H})$.

Synthesis of disazo dyes(containing UV absorber)4-6 ${ }^{(13)}$

$\mathrm{P}$. nitro aniline was diazotized by the following method: $\mathrm{p}$. nitro aniline $(1.38 \mathrm{gm}, 0.01 \mathrm{~mol})$ was dissolved in concentrated $\mathrm{HCl}(37 \%, 3 \mathrm{ml})$ and poured over ice $(50 \mathrm{gm})$ at $0{ }^{0} \mathrm{C}, \mathrm{NaNO}_{2}(0.72 \mathrm{gm})$ was added dropwise over $30 \mathrm{~min}$. The reaction mixture was stirred at $0{ }^{\circ} \mathrm{C}$ for $40 \mathrm{~min}$ and the excess nitrous acid was removed by adding a small amount of sulphamic acid. The resultant solution was added to $\mathrm{J}$ - acid $(2.4 \mathrm{gm}, 0.01 \mathrm{~mol})$ which dissolve in the appropriate amount of aqueous sodium carbonate at 5-6 ${ }^{0} \mathrm{C}$ over $30-45 \mathrm{~min}$ at ${ }_{\mathbf{p}} \mathrm{H}$ 8-9. The coupling was stirred until $\mathbf{P}_{\mathbf{P}} \mathrm{H}$ was stabled $\{\mathrm{T} 2\}^{(14)}$.

Then, the resultant mixture $\{\mathrm{T} 2\}$ was filtrated and diazotized in a similar manner as described above $\{\mathrm{T} 2 \mathrm{~A}\}$.

Reaction of T1A with resorcinol (dye 4): (T2A,0.01 mol) was treated with resorcinol (1.1 gm, $0.01 \mathrm{~mol})$ dissolved in $10 \%$ sodium hydroxide $(10 \mathrm{ml})$ and the mixture was stirred at ${ }_{\mathrm{P}} \mathrm{H} 8.5$ and $8-10{ }^{\circ} \mathrm{C}$ for $1 \mathrm{hr}$. The dye was salted out by addition of $\mathrm{NaCl}(15 \% \mathrm{w} / \mathrm{v})$ at $80{ }^{\circ} \mathrm{C}$. then filtrated and dried.

Dye 4: $\lambda=495 \mathrm{~nm}, \mathrm{mp}>300{ }^{\circ} \mathrm{C}$ yield $70 \%$.

IR (KBr) vmax $/ \mathrm{cm}^{-1}: 3446(\mathrm{OH}), 1485(\mathrm{~N}=\mathrm{N}), 1271,1217,1051\left(\mathrm{SO}_{3} \mathrm{H}\right)$.

${ }^{1} \mathrm{HNMR}$ (DMSO) ppm: $\delta 13.7,12.3,10.3 \mathrm{ppm}\left(\mathrm{s}, 3 \mathrm{H}, \mathrm{OH}\right.$ disappear in $\left.\mathrm{D}_{2} \mathrm{O}\right), 8.4$ $6.1 \mathrm{ppm}(\mathrm{m}, 11 \mathrm{H}$, aromatic $\mathrm{H})$.

Reaction of T2A with 2, 4- dihydroxy benzophenone (dye 5): (T2A,0.01 mol) was treated with 2,4 - dihydroxy benzophenone $(2.14 \mathrm{gm}, 0.01 \mathrm{~mol})$ dissolved in $10 \%$ sodium hydroxide $(16 \mathrm{ml})$,the mixture was stirred at ${ }_{\mathrm{p}} \mathrm{H}$ 8-9 and $8-10{ }^{\circ} \mathrm{C}$ for $1 \mathrm{hr}$. The dye was isolated by addition of $\mathrm{NaCl}(15 \% \mathrm{w} / \mathrm{v})$ at $80^{\circ} \mathrm{C}$ then filtrated and dried.

Dye 5: $\lambda=505 \mathrm{~nm}, \mathrm{mp}>300{ }^{\circ} \mathrm{C}$, yield $82 \%$.

IR (KBr) vmax $/ \mathrm{cm}^{-1}: 3441(\mathrm{OH}), 1623(\mathrm{C}=\mathrm{O}), 1483(\mathrm{~N}=\mathrm{N}), 1275,1112,1054\left(\mathrm{SO}_{3} \mathrm{H}\right)$. ${ }^{1} \mathrm{HNMR}$ (DMSO) ppm: $\delta 14,13.7,11.7 \mathrm{ppm}\left(\mathrm{s}, 3 \mathrm{H}, \mathrm{OH}\right.$ disappear in $\left.\mathrm{D}_{2} \mathrm{O}\right), 8.2$ $6.2 \mathrm{ppm}(\mathrm{m}, 15 \mathrm{H}$, aromatic $\mathrm{H})$.

Reaction of T2A with 1-hydroxy benzotriazol sulfonic acid (dye 6): (T2A,0.01 mol) was treated with 1 - hydroxy benzotriazol sulfonic acid $(2.15 \mathrm{gm}, 0.01 \mathrm{~mol})$, prepared in a similar way mentioned above, dissolved in $10 \%$ sodium hydroxide (20ml) , the mixture was stirred at ${ }_{\mathrm{P}} \mathrm{H} 8-9$ and $8-10{ }^{\circ} \mathrm{C}$ until ${ }_{\mathrm{P}} \mathrm{H}$ was stabled. The dye was salted out by addition of $\mathrm{NaCl}(15 \% \mathrm{w} / \mathrm{v})$ at $80{ }^{\circ} \mathrm{C}$ then filtrated and dried.

Dye 6: $\lambda=495 \mathrm{~nm}, \mathrm{mp}>300{ }^{\circ} \mathrm{C}$, yield $83 \%$.

IR (KBr) vmax $/ \mathrm{cm}^{-1}: 3445(\mathrm{OH}), 1496(\mathrm{~N}=\mathrm{N}), 1213,1106,1048\left(\mathrm{SO}_{3} \mathrm{H}\right)$.

${ }^{1} \mathrm{HNMR}$ (DMSO) ppm: $\delta 11.2,10.2 \mathrm{ppm}\left(\mathrm{s}, 2 \mathrm{H}, \mathrm{OH}\right.$ disappear in $\left.\mathrm{D}_{2} \mathrm{O}\right), 8.4-6.3$ $\operatorname{ppm}(\mathrm{m}, 10 \mathrm{H}$, aromatic $\mathrm{H})$.

Egypt. J. Chem. 55, No.5 (2012) 
Synthesis of disazo dyes(containing UV absorber)7-9 ${ }^{(13)}$

$\mathrm{P}$. Br Aniline was diazotized by the following method: $\mathrm{p}$. Br Aniline (1.72gm, $0.01 \mathrm{~mol})$ was dissolved in concentrated $\mathrm{HCl}(37 \%, 3 \mathrm{ml})$ and poured over ice $(50 \mathrm{gm})$ at $0{ }^{0} \mathrm{C} . \mathrm{NaNO}_{2}(0.72 \mathrm{gm})$ was added dropwise over $30 \mathrm{~min}$. The reaction mixture was stirred at $0{ }^{\circ} \mathrm{C}$ for $40 \mathrm{~min}$ and the excess nitrous acid was removed by adding a small amount of sulphamic acid.

The resultant solution was added to $\mathrm{J}$ - acid $(2.4 \mathrm{gm}, 0.01 \mathrm{~mol})$ which dissolved in the appropriate amount of aqueous sodium carbonate at $5-6{ }^{\circ} \mathrm{C}$, run over $30-45$ min, at ${ }_{\mathrm{P}} \mathrm{H}$ 8-9. The coupling was stirred until ${ }_{\mathrm{P}} \mathrm{H}$ was stabled $\{\mathrm{T} 3\}^{(14)}$.

Then, the resultant mixture $\{\mathrm{T} 3\}$ was filtrated and then diazotized in a similar manner as described above $\{\mathrm{T} 3 \mathrm{~A}\}$.

Reaction of T3A with resorcinol (dye 7): (T3A, $0.01 \mathrm{~mol}$ ) was treated with resorcinol $(1.1 \mathrm{gm}, 0.01 \mathrm{~mol})$ dissolved in $10 \%$ sodium hydroxide $(10 \mathrm{ml})$, the mixture was stirred at $8-10^{\circ} \mathrm{C}, \mathrm{H} 8.5$ for $1 \mathrm{hr}$. The dye was salted out by addition of $\mathrm{NaCl}(15 \% \mathrm{w} / \mathrm{v})$ at $80{ }^{\circ} \mathrm{C}$, then filtrated and dried.

Dye $7: \lambda=495 \mathrm{~nm}, \mathrm{mp}>300{ }^{\circ} \mathrm{C}$, yield $73 \%$.

IR (KBr) vmax/cm $\mathrm{cm}^{-1}: 3431(\mathrm{OH}), 1492(\mathrm{~N}=\mathrm{N}), 1264,1191,1049\left(\mathrm{SO}_{3} \mathrm{H}\right)$.

${ }^{1} \mathrm{HNMR}$ (DMSO) ppm: $\delta 13.2,12.6,10.5 \mathrm{ppm}\left(\mathrm{s}, 3 \mathrm{H}, \mathrm{OH}\right.$ disappear in $\mathrm{D}_{2} \mathrm{O}$ ), $8.1-5.7 \mathrm{ppm}(\mathrm{m}, 11 \mathrm{H}$, aromatic $\mathrm{H})$.

Reaction of T3A with 2, 4- dihydroxy benzophenone (Dye 8): (T3A,0.01 mol) was treated with 2,4 - dihydroxy benzophenone $(2.14 \mathrm{gm}, 0.01 \mathrm{~mol})$ dissolved in $10 \%$ sodium hydroxide $(16 \mathrm{ml})$, The mixture was stirred at $\mathrm{pH} 8-9,8-10^{\circ} \mathrm{C}$ for $1 \mathrm{hr}$. The dye was salted out by addition of $\mathrm{NaCl}(15 \% \mathrm{w} / \mathrm{v})$ at $80^{\circ} \mathrm{C}$ then filtrated and dried.

Dye 8: $\lambda=495 \mathrm{~nm}, \mathrm{mp}>300{ }^{\circ} \mathrm{C}$, yield $85 \%$.

IR (KBr) vmax $/ \mathrm{cm}^{-1}: 3443(\mathrm{OH}), 1623(\mathrm{C}=\mathrm{O}), 1494(\mathrm{~N}=\mathrm{N}), 1272,1123,1055\left(\mathrm{SO}_{3} \mathrm{H}\right)$.

${ }^{1} \mathrm{HNMR}$ (DMSO) ppm: $\delta 12.5,12.4,10.1 \mathrm{ppm}\left(\mathrm{s}, 3 \mathrm{H}, \mathrm{OH}\right.$ disappear in $\left.\mathrm{D}_{2} \mathrm{O}\right), 7.8$ $6.08 \mathrm{ppm}(\mathrm{m}, 15 \mathrm{H}$, aromatic $\mathrm{H})$.

Reaction of T3A with 1- hydroxy benzotriazol sulfonic acid (Dye 9): (T3A,0.01 mol) was treated with 1- hydroxy benzotriazol sulfonic acid $(2.15 \mathrm{gm}$, $0.01 \mathrm{~mol})$, prepared in a similar way mentioned above, dissolved in $10 \%$ sodium hydroxide $(20 \mathrm{ml})$, the mixture was stirred at $8-10{ }^{\circ} \mathrm{C},{ }_{\mathrm{p}} \mathrm{H}$ 8-9 until ${ }_{\mathrm{pH}} \mathrm{was}$ stabled. The dye was salted out by addition of $\mathrm{Nacl}(15 \% \mathrm{w} / \mathrm{v})$ at $80{ }^{\circ} \mathrm{C}$ then filtrated and dried.

Dye 9: $\lambda=495 \mathrm{~nm}, \mathrm{mp}>300{ }^{\circ} \mathrm{C}$, yield $82 \%$.

IR $(\mathrm{KBr})$ vmax $/ \mathrm{cm}^{-1}: 3454(\mathrm{OH}), 1495(\mathrm{~N}=\mathrm{N}), 1265,1191,1049\left(\mathrm{SO}_{3} \mathrm{H}\right)$.

${ }^{1} \mathrm{HNMR}$ (DMSO) ppm: $\delta 11.6,10.1 \mathrm{ppm}\left(\mathrm{s}, 2 \mathrm{H}, \mathrm{OH}\right.$ disappear in $\left.\mathrm{D}_{2} \mathrm{O}\right), 7.8-6.3$ ppm $(\mathrm{m}, 10 \mathrm{H}$, aromatic $\mathrm{H})$. 
Dyeing procedures, color measurements and fastness testing of the dyed samples Dyeing of nylon fabric

All dyeings were carried out in distilled water. The dyeing of nylon fabrics follows a traditional exhaustion dyeing procedure ${ }^{(16)}$. The dye baths were prepared with the (T1- T3) and synthesized dyes (1-9) at a range of dye conc. (0.5-3\% o.w.f). The $\mathrm{pH}$ of the dyeing bath was adjusted at $3,4,5,6,7$ and 8 by buffer solutions (acetic acid and/or sodium carbonate). The liquer ratio was kept at 1:50. The nylon fabrics were immersed into the dyeing bath at initial dyeing temperatures $40{ }^{\circ} \mathrm{C}$ for $10 \mathrm{~min}$, then the temperature raised to $60,70,80,90$ and $100{ }^{\circ} \mathrm{C}$ and the dyeing continued at these temp. for different time intervals (30$150 \mathrm{~min})$. After dyeing, all the dyed samples were washed with $(3 \mathrm{gm} / \mathrm{L})$ of non ionic detergent solution at $50{ }^{\circ} \mathrm{C}$ for $30 \mathrm{~min}^{(17)}$ and air dried.

\section{Color measurements}

Color strength: The colorimetric analysis of the dyed samples was performed using a Hunter Lab ultra Scan® PRO spectrophotometer.

The corresponding colour strength value (K/S) was assessed by applying the Kubelka Munk equation as follows ${ }^{(18)}$.

$$
\mathrm{K} / \mathrm{S}=(1-\mathrm{R})^{2} / 2 \mathrm{R}-\left(1-\mathrm{R}_{\mathrm{o}}\right)^{2} / 2 \mathrm{R}_{\mathrm{o}}
$$

where:

$\mathrm{R}=$ Decimal fraction of the reflectance of the dyed fabric.

$\mathrm{R}_{\mathrm{o}}=$ Decimal fraction of the reflectance of the undyed fabric.

$\mathrm{K}=$ Absorption coefficient.

$\mathrm{S}=$ Scattering coefficient.

Fastness testing: The dyed washed samples were tested by standard ISO methods. The specific testes were ISO 105-X12(1987), ISO 105-co4 (1989), ISO105-EO4 (1989), ISO 105-BO2 (1988) corresponding to color fastness to rubbing, washing, perspiration and light, respectively.

Irradiation: Samples 10x10 cm of dyed fabrics were mounted on a white chart paper and irradiated using a XENOTEST 1200 apparatus at a relative air humidity of $65 \%$ and $50{ }^{\circ} \mathrm{C}$ with duration from 35 to $175 \mathrm{hr}$.

The total color difference $(\triangle E)$

CIE lab difference: Now, in a lot of dye houses, there is a datamatch system which helps colorist to obtain different shades and to judge about the acceptance of these shades against a particular standard. The most widely used equation is CIE lab difference equation ${ }^{(16)}$.

$$
\Delta \mathrm{E}=\mathrm{L}^{2}+\left[\left(\mathrm{a}^{2}+\mathrm{b}^{2}\right)\right]^{1 / 2}
$$

$\Delta \mathrm{E}:$ the total difference between the sample and the stander.

a: represents the red - green axis.

b: the yellow - blue axis.

L: describes lightness. 


\section{Results and Discussion}

\section{Dyes structure}

The chemical structure of intermediate azo dyes (traditional dyes) (T1, T2, and T3) and synthesized anti-uv azo dyes (1-9) are given in Fig. 1 and 2.

\section{Elucidation of synthesized dyes structures}

IR analysis

The IR spectra of the synthesized dyes (1-9) showed the characteristic band at the range $3431 \sim 3454 \mathrm{~cm}^{-1}$, indicating the presence of $-\mathrm{OH}$ stretching vibration. The bands which appeared at $1474 \sim 1495 \mathrm{~cm}^{-1}$ are due to the stretching vibration of $-\mathrm{N}=\mathrm{N}$ - group. Three characteristic bands appeared at 1275, 1187, 1048 (e.g. dye 1) which indicate the presence of $-\mathrm{SO}_{3}$ group. The characteristic bands appeared at the range $1600 \sim 1680 \mathrm{~cm}^{-1}$ are due to the carbonyl groups $(-\mathrm{C}=\mathrm{O})$ stretching modes of dyes $2,5,8$.

\section{${ }^{I} H$-NMR analysis}

The chemical structures of the synthesized dyes are further confirmed by ${ }^{1} \mathrm{H}-$ NMR spectrum where dye (1) as an example, showed that, the peaks in the range

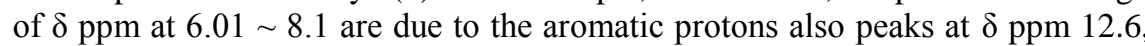
12.1, 10.4 are assigned to $\mathrm{OH}$ protons.<smiles>Nc1ccc2c(O)c(N=Nc3ccc(Cl)cc3)cc(S(=O)(=O)O)c2c1</smiles>

T1<smiles>Nc1ccc2c(O)c(N=Nc3ccc([N+](=O)[O-])cc3)cc(S(=O)(=O)O)c2c1</smiles>

T2<smiles>Nc1ccc2c(O)c(N=Nc3ccc(Br)cc3)cc(S(=O)(=O)O)c2c1</smiles>

Fig. 1. Intermediate azo dyes. (Traditional dyes) 
<smiles>O=S1(=O)C2=CC(N=Nc3ccc(Cl)cc3)=CC2=C(O)c2ccc(N=Nc3ccc(O)cc3O)cc21</smiles>

Dye1

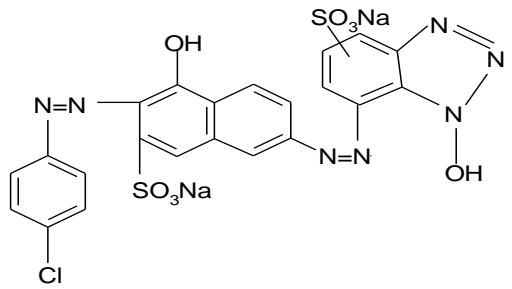

ye3<smiles></smiles>

Dye5<smiles>O=S(=O)(O)c1c(N=Nc2ccc(Br)cc2)c(O)c2ccc(N=Nc3ccc(O)cc3O)cc2[n+]1[O-]</smiles>

Dye7

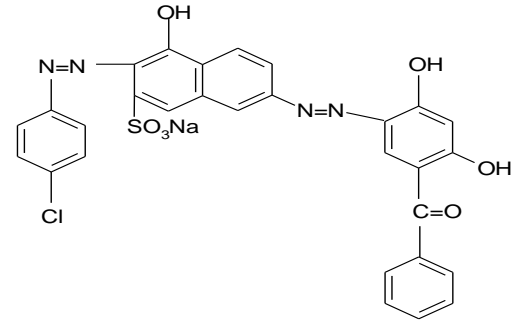

Dye2<smiles>O=[N+]([O-])c1ccc(N=Nc2c(S(=O)(=O)[O-])cc3cc(N=Nc4ccc(O)cc4O)ccc3c2O)cc1</smiles>

Dye4

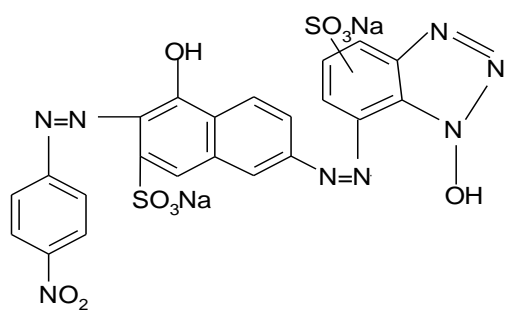

Dye6<smiles></smiles>

Dye8

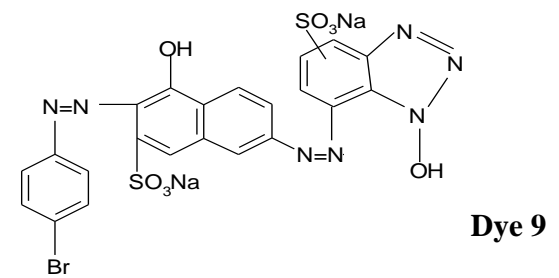

Fig. 2. Anti-UV azo dyes.

Egypt. J. Chem. 55, No.5 (2012) 
Dyeing performance and fastness properties of the synthesized anti-UV azo dyes Factors affecting dyeing of nylon fabrics

Effect of dyeing $\mathrm{pH}$ : Nylon fabrics $(0.5 \mathrm{~g})$ were dyed with $2 \%$ w.o.f intermediate azo dyes (T1, T2, T3) and anti- UV azo dyes (1-9) at pH (3-8) and L.R 1:50. Dyeing was continued for $60 \mathrm{~min}$ at $95^{\circ} \mathrm{C}$. After that, the dyed samples were rinsed, washed and air dried. The color strength $(\mathrm{K} / \mathrm{S})$ values of dyed washed samples were cited in Table 1. From Table 1 it can be observed that the higher color strength values for T1,T2, Dye6, Dye9 were obtained at $\mathrm{pH} 3$ while T3, Dye3, Dye4 give the highest color strength(K/S) values at $\mathrm{pH} 4$ and dyes Dye1, Dye2, Dye5, Dye7, Dye8 give higher color strength(K/S) at $\mathrm{pH} 5$.

TABLE 1. Effect of dyeing $\mathrm{pH}$ on the colour strength $(\mathrm{K} / \mathrm{S})$ values of nylon fabric dyed with dye intermediates (T1-T3) and anti-UV azo dyes (1-9) (2\% (w.o.f.), L.R 1:50, for $60 \mathrm{~min}$ ).

\begin{tabular}{|l|l|l|l|l|l|l|l|l|l|l|l|l|}
\hline \multirow{2}{*}{ PH } & \multicolumn{10}{|c|}{ Color strength (K/S) } \\
\cline { 2 - 16 } & T1 & T2 & T3 & Dye1 & Dye2 & Dye3 & Dye4 & Dye5 & Dye6 & Dye7 & Dye8 & Dye9 \\
\hline $\mathbf{3}$ & 27.84 & 25.93 & 21.1 & 25 & 21.51 & 19.18 & 23.02 & 11.54 & 22.17 & 23.25 & 21.1 & 22.17 \\
\hline $\mathbf{4}$ & 26.37 & 25.71 & 22.5 & 25.89 & 22.29 & 20.79 & 23.62 & 17.4 & 20.9 & 24.24 & 21.53 & 19.59 \\
\hline $\mathbf{5}$ & 26.14 & 24.03 & 21.69 & 27.01 & 25.28 & 19.79 & 21.23 & 22.02 & 18.9 & 26.89 & 23.16 & 17.57 \\
\hline $\mathbf{6}$ & 25.22 & 23.43 & 19.39 & 26.65 & 22.63 & 18.08 & 19.19 & 10.18 & 15.01 & 23.8 & 21.84 & 17.21 \\
\hline $\mathbf{7}$ & 21.41 & 22.58 & 19.13 & 23.6 & 21.49 & 17.61 & 19.74 & 8.78 & 11.67 & 21.92 & 18.54 & 14.26 \\
\hline $\mathbf{8}$ & 19.23 & 16.73 & 13.12 & 21.77 & 20.46 & 12.43 & 12.93 & 5.93 & 6.19 & 20.93 & 17.4 & 13.99 \\
\hline
\end{tabular}

Effect of dyeing temperature: Nylon fabrics $(0.5 \mathrm{~g})$ were dyed with $2 \%$ w.o.f intermediate azo dyes (T1, T2, T3) and anti- UV azo dyes (1-9) at the suitable $\mathrm{pH}$ and L.R 1:50. Dyeing was continued for $60 \mathrm{~min}$ and temperature varied from $\left(60-100^{\circ} \mathrm{C}\right)$. After that, the dyed samples were rinsed, washed and air dried. Data of color strength $(\mathrm{K} / \mathrm{S})$ for dyed washed samples were listed in Table 2.

From Table 2 it can be seen that increasing temperature from 60 to $80^{\circ} \mathrm{C}$ leads to a slight increase in color yield values $(\mathrm{K} / \mathrm{S})$. Increasing temperature more than $80^{\circ} \mathrm{C}$ leads to an improvement in color yield values. The maximum dyeability and color strength were obtained at $100^{\circ} \mathrm{C}$, this holds true for all dyes used.

TABLE 2. Effect of dyeing temperature on the colour strength $(\mathrm{K} / \mathrm{S})$ values of nylon fabric dyed with dye intermediates (T1-T3) and anti-UV azo dyes (1-9) (2\% (w.o.f.), L.R 1:50, for $60 \mathrm{~min}$ ).

\begin{tabular}{|c|c|c|c|c|c|c|c|c|c|c|c|c|}
\hline \multirow{2}{*}{ Temp. } & \multicolumn{10}{|c|}{ Color strength (K/S) } \\
\cline { 2 - 15 } & T1 & T2 & T3 & Dye1 & Dye2 & Dye3 & Dye4 & Dye5 & Dye6 & Dye7 & Dye8 & Dye9 \\
\hline $\mathbf{6 0}$ & 24.08 & 21.36 & 20.93 & 21.05 & 12.39 & 16.3 & 22.42 & 18.79 & 20.82 & 21.8 & 11.7 & 20.33 \\
\hline $\mathbf{7 0}$ & 25.95 & 22.56 & 21.69 & 21.63 & 13.13 & 16.43 & 23.1 & 18.87 & 20.96 & 24.24 & 12.9 & 21.27 \\
\hline $\mathbf{8 0}$ & 26 & 22.7 & 22.53 & 22.02 & 13.72 & 18.03 & 24.16 & 19.12 & 21.19 & 25.05 & 14.45 & 21.77 \\
\hline $\mathbf{9 0}$ & 26.45 & 24.47 & 22.59 & 22.78 & 14.51 & 20.17 & 24.21 & 19.36 & 21.59 & 25.13 & 15.25 & 22.29 \\
\hline $\mathbf{1 0 0}$ & 27.07 & 25.4 & 22.69 & 22.91 & 15.33 & 20.62 & 24.37 & 20.02 & 21.68 & 25.5 & 19.78 & 23.48 \\
\hline
\end{tabular}


Effect of dyeing time: Nylon fabrics $(0.5 \mathrm{~g})$ were dyed with $2 \%$ w.o.f. intermediate azo dyes (T1, T2, T3) and anti- UV azo dyes (1-9) at the suitable pH and L.R 1:50, at $100^{\circ} \mathrm{C}$ and time was varied from (30-150 min). After that, the dyed samples were rinsed, washed and air dried .The color strength for the dyed washed samples were tabulated in Table 3.

From Table 3 it can be seen that increasing dyeing time from 30 min to 60 min leads to an increase in $\mathrm{K} / \mathrm{S}$ for all dyes. After $60 \mathrm{~min}$ dyeing, the colour strength values nearly levels off or a very slight improvement takes place.

TABLE 3. Effect of dyeing time on the colour strength (K/S) values of nylon fabric dyed with dye intermediates (T1-T3) and anti-UV azo dyes (1-9) $(2 \%$ (w. o. f.), L. R 1:50, dyeing temperature: $100^{\circ} \mathrm{C}$ ).

\begin{tabular}{|c|c|c|c|c|c|c|c|c|c|c|c|c|}
\hline \multirow{2}{*}{ Time } & \multicolumn{10}{|c|}{ Color strength (K/S) } \\
\cline { 2 - 12 } & T1 & T2 & T3 & Dye1 & Dye2 & Dye3 & Dye4 & Dye5 & Dye6 & Dye7 & Dye8 & Dye9 \\
\hline $\mathbf{3 0}$ & 23.05 & 24.25 & 20.39 & 19.3 & 13.24 & 17.15 & 22.24 & 18.06 & 19.05 & 21.48 & 19.88 & 11.55 \\
\hline $\mathbf{6 0}$ & 23.86 & 24.78 & 21.05 & 20.39 & 13.84 & 20.06 & 22.42 & 18.46 & 19.78 & 21.85 & 22.79 & 19.81 \\
\hline $\mathbf{9 0}$ & 24.34 & 24.87 & 21.36 & 21.68 & 14.87 & 20.41 & 22.87 & 18.61 & 20.13 & 22.18 & 23.08 & 20.84 \\
\hline $\mathbf{1 2 0}$ & 24.41 & 25.55 & 23.74 & 23.76 & 16.15 & 21.01 & 22.95 & 18.79 & 20.64 & 24.21 & 23.4 & 20.9 \\
\hline $\mathbf{1 5 0}$ & 24.78 & 27.53 & 23.84 & 25.9 & 23.16 & 26.00 & 25.24 & 19.02 & 21.27 & 25.07 & 25.64 & 24.16 \\
\hline
\end{tabular}

Effect of dye concentrations: Nylon fabrics (0.5g) were dyed with intermediate azo dyes (T1, T2, T3) and anti- UV azo dyes (1-9), (0.5\%-3\% w.o.f.) at the suitable $\mathrm{pH}$ and L.R 1:50, at $100^{\circ} \mathrm{C}$ for $60 \mathrm{~min}$, then, the dyed samples were rinsed, washed and air dried. The color strength (K/S) were measured and cited in Table 4.

Table 4 shows that as the dye concentration increases from $0.5 \%$ to $3 \%$, the color strength also increases for all dyes.

TABLE 4. Effect of dye concentration on the color strength $(K / S)$ values of nylon fabric dyed with dye intermediates (T1-T3) and anti-UV azo dyes (1-9) (L.R 1:50, dyeing temp $100{ }^{\circ} \mathrm{C}$ for $60 \mathrm{~min}$ ).

\begin{tabular}{|c|c|c|c|c|c|c|c|c|c|c|c|c|}
\hline \multirow{2}{*}{$\begin{array}{c}\text { Conc. } \\
\%\end{array}$} & \multicolumn{12}{|c|}{ Color strength $(\mathrm{K} / \mathrm{S})$} \\
\hline & T1 & $\mathbf{T} 2$ & T3 & Dye1 & Dye2 & Dye3 & Dye4 & Dye5 & Dye6 & Dye7 & Dye8 & Dye9 \\
\hline 0.5 & 18.71 & 12.13 & 4.83 & 17.95 & 6.47 & 6.21 & 13.84 & 5.36 & 5.04 & 10.55 & 5.44 & 3.7 \\
\hline 1 & 25.26 & 23.41 & 13.56 & 23.23 & 11.46 & 14.25 & 18.3 & 5.93 & 12.33 & 20.34 & 13.82 & 13.74 \\
\hline 1.5 & 25.53 & 23.49 & 18.08 & 24.21 & 18.71 & 18.96 & 20.33 & 17.63 & 17.28 & 24.25 & 20.86 & 16.57 \\
\hline 2 & 26.9 & 24.88 & 21.8 & 25.3 & 23.81 & 19.7 & 20.93 & 19.33 & 18.79 & 25.2 & 21.66 & 19.54 \\
\hline 2.5 & 27.51 & 25.61 & 22.75 & 25.73 & 24.66 & 24.43 & 22.36 & 21.36 & 22.12 & 26.46 & 22.74 & 19.91 \\
\hline 3 & 29.03 & 26.27 & 24.86 & 26.45 & 24.67 & 24.6 & 24.7 & 21.66 & 22.81 & 27.09 & 25.54 & 24.44 \\
\hline
\end{tabular}

Egypt. J. Chem. 55, No.5 (2012) 
Fastness properties: Fastness properties of intermediate dyes and anti-UV dyes (T1-T3, Dye1-Dye9) are shown in Table 5. Results show very good fastness properties for croking for both intermediate dyes and anti UV dyes, as for washing and perspiration fastness properties the anti UV dyes show better fastness compared with intermediate dyes ranging from good to very good.

Light fastness also improved for anti-UV dyes against intermediate dyes showing very good light fastness.

TABLE 5. Fastness properties of dye intermediates (T1-T3) and anti-uv azo dyes (1-9) ( $2 \%$ dye, L.R 1:50 and dyeing for $60 \mathrm{~min}$ at $100{ }^{\circ} \mathrm{C}$ ).

\begin{tabular}{|c|c|c|c|c|c|c|c|c|c|c|c|c|}
\hline \multirow[t]{2}{*}{ Dyes } & \multicolumn{2}{|c|}{$\begin{array}{c}\text { Crocking } \\
\text { fastness }\end{array}$} & \multicolumn{3}{|c|}{$\begin{array}{l}\text { Washing } \\
\text { fastness }\end{array}$} & \multicolumn{3}{|c|}{$\begin{array}{c}\text { Acidic } \\
\text { perspiration }\end{array}$} & \multicolumn{3}{|c|}{$\begin{array}{c}\text { Alkaline } \\
\text { perspiration }\end{array}$} & \multirow[t]{2}{*}{$\begin{array}{c}\text { Light } \\
\text { fastness }\end{array}$} \\
\hline & Dry & Wet & St.* & St. ** & Alt. & St.* & St. ** & Alt. & St.* & St.** & Alt. & \\
\hline T1 & $4-5$ & $4-5$ & $2-3$ & 3 & 3 & $2-3$ & 3 & 3 & $2-3$ & 3 & 3 & $5-6$ \\
\hline Dye1 & $4-5$ & $4-5$ & 3 & $3-4$ & 3 & 3 & $3-4$ & 3 & 3 & 4 & 4 & 6 \\
\hline Dye2 & $4-5$ & 4 & $3-4$ & $4-5$ & 4 & $3-4$ & 4 & 4 & $3-4$ & 4 & 4 & $6-7$ \\
\hline Dye3 & $4-5$ & $4-5$ & $3-4$ & $4-5$ & 4 & $3-4$ & 4 & 4 & $3-4$ & 4 & 4 & $6-7$ \\
\hline $\mathbf{T 2}$ & $4-5$ & 4 & 3 & $3-4$ & 3 & $2-3$ & 3 & 3 & $2-3$ & $2-3$ & 2 & $5-6$ \\
\hline Dye4 & $4-5$ & 4 & $4-5$ & $4-5$ & 4 & 4 & 4 & 4 & $4-5$ & $4-5$ & 4 & 6 \\
\hline Dye5 & $4-5$ & 4 & $4-5$ & $4-5$ & 4 & $4-5$ & $4-5$ & 4 & $4-5$ & 4 & 4 & $6-7$ \\
\hline Dye6 & $4-5$ & 4 & $4-5$ & $4-5$ & 4 & $4-5$ & $4-5$ & 4 & $4-5$ & 4 & 4 & $6-7$ \\
\hline T3 & $4-5$ & $4-5$ & $2-3$ & 3 & 3 & $2-3$ & 3 & 3 & $2-3$ & 3 & 3 & $5-6$ \\
\hline Dye7 & $4-5$ & $4-5$ & 3 & $4-5$ & 3 & 3 & 4 & 4 & 4 & 4 & 4 & 6 \\
\hline Dye8 & $4-5$ & $4-5$ & $3-4$ & $4-5$ & 4 & 3 & 4 & 4 & 4 & 4 & 4 & $6-7$ \\
\hline Dye9 & $4-5$ & $4-5$ & $3-4$ & $4-5$ & 4 & 3 & 4 & 4 & 4 & 4 & 4 & $6-7$ \\
\hline
\end{tabular}

St. $*$ = Staining on cotton

St. $* *=$ Staining on wool

Alt. = Alteration in color

The total color difference $(\Delta E)$ : From Table 6 , it can be observed that with increasing time of irradiation of dyed nylon samples, the rate of fading increases for all dye intermediates $\mathrm{T} 1, \mathrm{~T} 2$ and $\mathrm{T} 3$ following the order $\mathrm{T} 3>\mathrm{T} 1>\mathrm{T} 2$. This can be attributed to the electro negativity of $\mathrm{NO}_{2}>\mathrm{Cl}>\mathrm{Br}$ groups.

The rate of fading for nylon samples dyed with Dye1-9 is less than that for samples dyed with T1-T3. This can be explained by the presence of anti ultraviolet functional finishing group in dyes structure.

For dyed samples with Dye1-3, it can be observed that the light fading of samples dyed with Dye3 is less than that with Dye2 and Dye1 following the order Dye1 > Dye2> Dye 3. This can be attributed to the greater reactivity of triazol present in 1- hydroxy benzotriazol sulfonic acid anti UV in Dye3, Dye6 and Dye 9, also, due to the presence of carbonyl group in 2,4-dihydroxy benzophenone in Dye2, Dye5 and Dye8. 
TABLE 6. The rate of fading of nylon fabric dyed with dye intermediates (T1-T3) and anti-UV azo dyes (1-9).

\begin{tabular}{|c|c|c|c|c|c|c|c|c|c|c|c|c|c|}
\hline $\begin{array}{c}\text { Time of } \\
\text { Irradiation } \\
\text { In hr }\end{array}$ & & T1 & Dye1 & Dye2 & Dye3 & $\mathbf{T 2}$ & Dye4 & Dye5 & Dye6 & T3 & Dye7 & Dye8 & Dye9 \\
\hline \multirow{4}{*}{ Ohr } & $\mathrm{L}$ & 50.55 & 31.59 & 33.54 & 29.28 & 38.09 & 32.33 & 31.6 & 28.4 & 46.62 & 30.40 & 31.00 & 29.50 \\
\hline & $\mathrm{a}$ & 22.85 & 36.87 & 33.80 & 34.53 & 25.73 & 26.38 & 29.66 & 30.32 & 34.46 & 36.37 & 33.67 & 32.51 \\
\hline & b & 21.06 & 13.08 & 16.54 & 13.34 & 20.28 & 22.46 & 17.82 & 15.35 & 37.87 & 17.48 & 20.66 & 16.82 \\
\hline & $\Delta \mathrm{E}$ & 59.34 & 51.78 & 50.41 & 47.20 & 50.24 & 47.58 & 47.04 & 44.29 & 60.53 & 50.52 & 50.22 & 47.02 \\
\hline \multirow{4}{*}{$35 \mathrm{hr}$} & $\mathrm{L}$ & 53.58 & 35.07 & 33.79 & 29.27 & 34.42 & 33.09 & 31.81 & 28.9 & 48.73 & 34.95 & 38.73 & 34.02 \\
\hline & $\mathrm{a}$ & 19.12 & 34.44 & 33.98 & 34.91 & 31.61 & 25.21 & 25.58 & 29.77 & 24.60 & 32.29 & 30.15 & 31.03 \\
\hline & b & 17.85 & 20.21 & 17.15 & 13.83 & 18.75 & 21.45 & 20.42 & 16.01 & 25.06 & 21.88 & 18.08 & 15.60 \\
\hline & $\Delta \mathrm{E}$ & 59.63 & 53.15 & 51.10 & 47.61 & 50.65 & 47.06 & 45.64 & 44.48 & 61.47 & 52.37 & 52.31 & 48.62 \\
\hline \multirow{4}{*}{$70 \mathrm{hr}$} & $\mathrm{L}$ & 45.48 & 44.03 & 40.70 & 29.63 & 42.53 & 35.31 & 33.86 & 30.25 & 50.47 & 38.65 & 35.96 & 38.10 \\
\hline & $\mathrm{a}$ & 17.75 & 26.94 & 29.83 & 34.84 & 22.78 & 24.21 & 24.47 & 27.88 & 22.72 & 29.96 & 33.25 & 28.38 \\
\hline & b & 16.62 & 18.07 & 18.77 & 13.76 & 19.42 & 21.49 & 21.36 & 20.05 & 24.04 & 21.53 & 18.58 & 15.01 \\
\hline & $\Delta \mathrm{E}$ & 59.66 & 54.69 & 53.84 & 47.76 & 52.00 & 48.34 & 46.92 & 45.77 & 62.56 & 53.43 & 52.38 & 49.82 \\
\hline \multirow{4}{*}{$105 \mathrm{hr}$} & $\mathrm{L}$ & 47.64 & 48.19 & 47.86 & 30.59 & 48.17 & 32.92 & 37.44 & 29.53 & 46.07 & 42.11 & 44.61 & 41.77 \\
\hline & $\mathrm{a}$ & 26.82 & 24.12 & 22.93 & 35.19 & 18.79 & 27.35 & 24.38 & 30.54 & 29.10 & 27.67 & 25.13 & 25.17 \\
\hline & b & 25.03 & 17.65 & 16.22 & 14.43 & 17.89 & 23.45 & 17.94 & 16.07 & 30.14 & 20.19 & 15.39 & 14.18 \\
\hline & $\Delta \mathrm{E}$ & 60.13 & 56.71 & 55.50 & 48.81 & 54.71 & 48.91 & 48.14 & 45.42 & 62.93 & 54.28 & 53.47 & 50.77 \\
\hline \multirow{4}{*}{$140 \mathrm{hr}$} & $\mathrm{L}$ & 44.52 & 51.05 & 44.30 & 30.59 & 49.3 & 32.00 & 37.81 & 29.76 & 48.63 & 45.35 & 46.07 & 47.72 \\
\hline & a & 31.07 & 21.37 & 27.57 & 35.19 & 17.42 & 29.77 & 22.62 & 29.59 & 26.79 & 23.90 & 22.71 & 19.35 \\
\hline & b & 31.53 & 16.47 & 19.00 & 14.43 & 16.62 & 22.68 & 21.84 & 16.5 & 28.74 & 18.29 & 15.01 & 12.32 \\
\hline & $\Delta \mathrm{E}$ & 62.78 & 57.74 & 55.53 & 48.81 & 54.71 & 49.5 & 49.17 & 45.33 & 64.61 & 54.43 & 53.51 & 53.06 \\
\hline \multirow{4}{*}{$175 \mathrm{hr}$} & $\mathrm{L}$ & 45.68 & 55.10 & 47.98 & 31.31 & 56.60 & 42.12 & 43.78 & 31.09 & 45.46 & 46.16 & 47.06 & 46.42 \\
\hline & $\mathrm{a}$ & 36.22 & 17.24 & 23.10 & 34.70 & 12.15 & 30.55 & 17.42 & 30.59 & 36.63 & 23.23 & 22.07 & 22.67 \\
\hline & b & 44.89 & 13.83 & 16.72 & 14.45 & 12.86 & 26.2 & 19.21 & 17.7 & 44.40 & 18.01 & 14.51 & 13.92 \\
\hline & $\Delta \mathrm{E}$ & 73.35 & 59.37 & 55.82 & 48.92 & 59.3 & 52.33 & 50.89 & 47.07 & 73.58 & 54.72 & 53.97 & 53.50 \\
\hline
\end{tabular}

Egypt. J. Chem. 55, No.5 (2012) 


\section{Conclusion}

Novel nine azo dyes containing anti-UV absorbers (anti- UV dyes) were prepared using primary aromatic amines ( $\mathrm{P} . \mathrm{No}_{2}, \mathrm{Cl}, \mathrm{Br}$ aniline) and $\mathrm{J}-$ acid coupler. Resorcinol, 2, 4- dihydroxy bezophenone and 1- hydroxyl benzotriazol sulfonic acid were used as UV absorbers. Polyfunctional dyes; Dye3, Dye6, Dye9 containing 1- hydroxyl benzotriazol sulfonic acid anti UV absorber gives less fading than other dyes, due to the presence of triazol group followed by Dye2, Dye5, Dye8 which have 2, 4- dihydroxy bezophenone as a UV absorber. Dye1, Dye4, Dye7 containing resorcinol as UV absorber give the highest fading results.

\section{References}

1. Wang, Q. and Hauser, P.J., Developing a novel UV protection process for cotton based on layer-by-layer self-assembly. Carbohydr polymers, 81, $491-496$ (2010).

2. Feng, X.X., Zhang, L.L., Chen, J.Y. and Zhang, J.C., New insights into solar UVprotective properties of natural dye. Journal of Cleaner Production, 15, 366-372 (2007).

3. Czajkowski, W., Paluszkiewicz, J., Stolaski, R., Kazmieska, M. and Gresiak, E. , Synthesis of reactive UV absorbers, derivatives of monochlorotriazine, for improvement in protecting properties of cellulose fabrics. Dyes and Pigmants, 71, 224-230 (2006).

4. Frank, W., Juergen, K., Anjap., F., Horst, E.A., David, L. and Gerhard R., Ultraviolet absorbers and singlet oxygen. Journal of Photochemistry and Photobiology Aichemistry, 126, 43-49(1999).

5. Daniele, G., Bacci, L., Zipoli, G., Carreras, G., Silvia, B. and Sabatini, F., Laboratory and outdoor assessment of UV protection offered by flax and hemp fabrics dyed with natural dyes. Photochemistry and Photobiology, 85, 313-320(2009).

6. Ibrahim, N.A., Refai, R., Youssef, M.A. and Ahmed, F., Proper finishing treatments for sun-protective cotton-containing fabrics. Journal of Applied Polymer Science, 97, 1024-1032(2005).

7. Mahltig, B., Bottcher, H., Rauch, K., Dieckmann, U., Nitsche, R. and Fritz, T., Optimized UV protecting coatings by combination of organic and inorganic UV absorbers.Thin Solid Films, 108-114(2005).

8. Maged, H., Zohdy,A., Mamdouh, B., El Hossamy, B., Abdel Wahab,M., ElNaggar, A., Abeer,I., Fathalla, B., Nisreen, M. and Ali, A., Novel UV-protective formulations for cotton, PET fabrics and their blend utilizing irradiation technique. European Polymer Journal, 45, 2926-2934(2009). 
9. Lee, J.J., Lee, H.H., Eom, S.I. and Kim, J.P., UV absorber after treatment to improve light fastness of natural dyes on protein fibres.Color. Technol.117, 134(2001).

10. Daniele, G., Bacci, L., Zipoli, G., Carreras, G., Baronti, S. and Francesco, S., Laboratory and outdoor assessment of UV protection offered by flax and hemp fabrics dyed with natural dyes. Photochemistry and Photobiology, 85, 313-320 (2009).

11. Lapidot, N., Gans, O., Biagini, F., Sosonkin, L. and Rottman, C., Advanced sunscreens: UV absorbers encapsulated in sol-gel glass microcapsules. J. Sol. Gel Sci. Technol. 26, 67(2003).

12. Rajagopal, R. and Seshadri, S., Light-stabilised azo dyes containing a built-in ultraviolet absorber residue. Dyes and Pigmantes, 9, 233-241 (1988).

13. David, R. and H. Geoffrey, H., The Chemistry and Application of Dyes. Dyes for cellulosic fibers, chapter 3, 94-95 (1990).

14. Blangey, E., Fierz, H.E. and Stamm Helv, O.A., Uber die sulfierung des athylbenzyl-anilins. Chem. Acta, 25, 1162 (1942).

15. Rita Degiorgi, M., Rosarina, C. and Guido, G., Structure optimization in a series of acid dyes for wool and nylon. Dyes and Pigmants, 34, 1, 11-12 (1997).

16. Williams, S., Practical colour management. Optics \& Laser Technology, 38, 399-404 (2006).

17. Kubelka, N.A. and Munk, F., Ein Beitrag zur Optik der Farbanstriche.Z. Tech. Phys, 12, 593-601 (1931). 


\section{تثيد صبغات وظيفية مضادة للأشعة فوق البنفسجية وتطبيقاتها فى صباغة الياف النيلون}

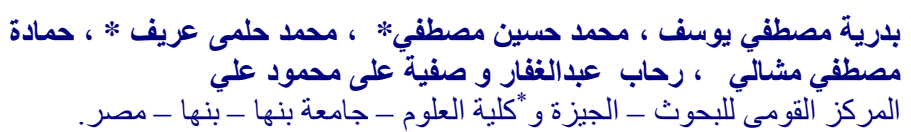

تم تحضيرتسـعة مـن صبغات الأزو الجديدة التى تحتوى على مجموعـات

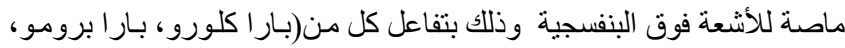

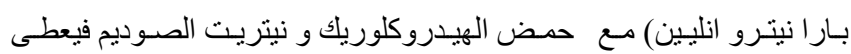

مركب الأزو و الذى بدورة يتحد مع (J-acid) الذائبة فى كربونـات الصوديم

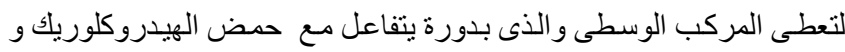

نيتريت الصـوديم فيعطى مركب الأزو و الذى بدورة يتحد مـع المو اد الماصـة

لكأشعة فوق البنفسجية

(Resorcinol, 2, 4- dihydroxy benzophenone, 1- hydroxyl

benzotriazol sulfonic acid).

•ـــــــات التركيـب الكيميـائى لهذذة الصـبخات عـن طريـق التحاليـل الطيفيـة

المعروفة

.( IR, $\left.{ }^{1} \mathrm{H}-\mathrm{NMR}\right)$

• تم استخدام هذة الصبغات فى صباغة الياف النيلون

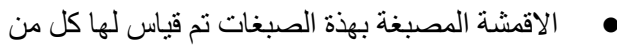

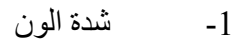

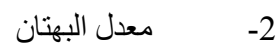

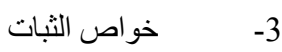

Egypt. J. Chem. 55, No.5 (2012) 